Kovesi, $\mathrm{S}$

Finding poems, making text: John Clare and the greening of textual criticism.

Kovesi, S (2011) Finding poems, making text: John Clare and the greening of textual criticism.

Romanticism, 17 (2). pp. 135-147.

Doi: 10.3366/rom.2011.0019

This version is available: https://radar.brookes.ac.uk/radar/items/655d32fc-7169-17f4-9b27-7b4d8dabe01f/1/

Available on RADAR: October 2012

Copyright (C) and Moral Rights are retained by the author(s) and/ or other copyright owners. A copy can be downloaded for personal non-commercial research or study, without prior permission or charge. This item cannot be reproduced or quoted extensively from without first obtaining permission in writing from the copyright holder(s). The content must not be changed in any way or sold commercially in any format or medium without the formal permission of the copyright holders.

This document is the published version of the journal article. 


\section{Finding Poems, Making Text: John Clare and the Greening of Textual Criticism}

Keywords: nature, inspiration, creativity, ecocriticism, textual criticism, eco-editing

There are two lines in Clare's work which have become talismanic. They have served as a catalyst for many critics, and will do so for this essay too. The first reference to the lines we will visit is not the earliest and is perhaps the least analytical of all. But it is the one which confirms that, just thirteen years after the poet's death, these lines had become the signpost indicating that Clareness was close by. In 1876 Frederick Williams writes:

Passing Helpstone, where John Clare, the Northamptonshire poet was born, in 1793, of parents even then receiving parish relief, and who tells us of his literary gifts,-

'I found the poems in the fields, And only wrote them down,'-

we soon reach Peterborough, join the Great Northern Railway, enter its station, and then taking our way down to the Great Eastern, find there the end of our journey.

These lines alone form the signifier sufficient for passing local interest as Williams dashes past Helpston on the Syston and Peterborough line, in his extensive and detailed history of the 'mighty and beneficent revolution' and 'modern enterprise ${ }^{1}$ of the Midland railway network. Steamed-up modernity has no time to ponder: on we must go.

The lines maintained their talismanic position way into the twentieth century, coming to stand for something inexpressibly Clare-like, for some vague and often unexplained essence of what Clare is about. Cecil Day Lewis uses the lines as evidence of Clare's 'hyperaesthesia' - he just cannot help himself: writing is urgently instinctual and uncontrollable. ${ }^{2}$ Without much commentary to speak of, Harold Bloom slots the lines into his argument that Clare sought comfort-but ultimately withered - in Wordsworth's shadow. ${ }^{3}$ Abruptly, Paul Chirico says the lines offer a 'conventionally naïve literary model', which amounts to a 'claim that has long been recognised as disingenuous'. ${ }^{4}$ Most recently, in the bathetically entitled Can Poetry Save the Earth? John Felstiner deploys the two lines to affirm Clare's 'humbleness' before the natural world. ${ }^{5}$ But of all uses by twentieth- and twenty-first-century commentators, most interesting is the role the lines play in John Ashbery's mystical version of Clare, which I will quote at length:

What he sees, he is... The sudden, surprising lack of distance between poet and reader is in proportion to the lack of distance between the poet and the poem; he is the shortest distance between poem and reader.

Romanticism 17.2 (2011): 135-147

DOI: 10.3366/rom.2011.0019

(C) Edinburgh University Press

www.eupjournals.com/rom 
We are far from emotion recollected in tranquillity or even the gently shaping music of Keats's grasshopper sonnet. Clare's poems are dispatches from the front. 'I found the poems in the fields / and only wrote them down,' he wrote, and he tells us that a favorite method of composing was in the open, using his hat as a writing desk. The resulting plein-air effect is similar to the studies of John Constable, Clare's exact contemporary. In the case of both, the point is that there is no point. Clare is constantly wandering, in his circumscribed domain, but there is not much to see; the land is flat and fenny and devoid of 'prospects.' Unlike Wordsworth's exalted rambles in 'The Prelude,' there is no indication that all this is leading up to something... ${ }^{6}$

Ashbery revels in the aimless, nomadic wandering of Clare, and does not condemn the poetry for being unaware of its own direction. The first clipped sentence of this passage is tersely summative of what follows. Ashbery's model of Clare squeezes out the Cartesian thought process: not 'I think, therefore I am' but 'What he sees, he is'. Seeing erases thought - and Ashbery's phrase even erases the Cartesian conjunction, 'therefore' (or rather, 'donc' or 'ergo' in Descartes' original uses of the famous phrase in French and Latin respectively). Ashbery elides the possibility of awareness of the relationship between seeing and being. He reads a process where the perception of something is immediately incorporated with it. Somehow, Clare successfully closes the gap between perception and existence, between subject and object, but without thought getting in the way. This essay will interrogate the purpose and positioning of the closure of the gap between human subject and natural object to which Clare appears to lay a foundational claim (and over which Ashbery is so impressed), eventually to inform a prospective methodology for the presentation of Clare's texts.

\section{Victorian Clare: Cyrus Redding and Edwin} PAXTON HoOd

None of the critics mentioned so far quote the poem from which they each extract the talismanic lines. 'Sighing for Retirement' was first published in an essay by Cyrus Redding in The English Journal of 15 May 1841. There is no holograph copy of the poem, nor any manuscript version by an amanuensis known to Clare. The only version we have, therefore, has been through the textual mill of the recipient who was also The English Journal's editor, Redding, an extensively experienced and well-connected man of letters (most notably editor of the New Monthly Magazine, from 1821-30); the title of the poem might be Redding's - we simply cannot know. We are therefore at a considerable remove from an 'original' textual source; how much editorial tidying and polishing of Clare's original text was carried out by Redding, likewise we can never know. Having visited Clare in the High Beech asylum in Essex where he acquired this and other unpublished poems, Redding reads the verse as a testament to the improvement of Clare's mental state since beginning his residence as a voluntary patient in 1837 . For Redding, it was reassuring that the poet was still able to write well about the 'agreeable situation' of the asylum in Epping Forest. After Clare's death, in a revised account of the meeting, Redding admits he was unsure as to why Clare was in the asylum at all, and so was the medic who ran the place, Matthew Allen: 'the Doctor said that Clare's mind was so slightly affected that he thought it might be as well if he were at home with his friends' ${ }^{8}$ Here is the poem in full, as it appeared in 1841 : 
O TAKE me from the busy crowd, I cannot bear the noise!

For Nature's voice is never loud; I seek for quiet joys.

The book I love is everywhere, And not in idle words;

The book I love is known to all, And better lore affords.

The book I love is everywhere, And every place the same;

GoD bade me make my dwelling there, And look for better fame.

I never feared the critic's pen, To live by my renown;

I found the poems in the fields, And only wrote them down.

And quiet Epping pleases well, Where Nature's love delays;

I joy to see the quiet place, And wait for better days.

I love to see the brakes and fern, And rabbits up and down;

And then the pleasant Autumn comes, And turns them all to brown.

To common eyes they only seem A desert waste and drear;

To taste and love they always shine, A garden through the year.

LORD keep my love for quiet joys, Oh, keep me to thy will!

I know THY works, and always find THY mercies kinder still!

The first critical response to this poem appeared ten years later, written by Edwin Paxton Hood (1820-1885). Hood was a dissenting Congregationalist minister who promoted the cause, value and special cases of labouring-class poets in the middle of the nineteenth century. He was prolific in many other areas - publishing over fifty books between 1846 and $1886^{\circ}$ (including collections of sermons, self-help books, educational and ethical treatises, works theorising biography, one on the morality of laughter, a number of works on anecdotes, two on Englishness, one on Scottishness, two polemics on Jamaica, and separate biographical studies of Cromwell, Milton, Marvell, Watts, Wordsworth, Carlyle, Swedenbourg, and Queens Mary and Elizabeth). In the midst of this activity, Hood published three closely-related works on the poor and art, entitled The Literature of Labour and Genius and Industry (both of 1851), and a revision, compendium and expansion of these two books in The Peerage of Poverty; or, Learners and Workers in Fields, Farms, and Factories (first edition 1859, repeatedly revised and expanded until its final, celebrated fifth edition of 1870).

One of the founding voices of modern Clare criticism, Mark Storey, considers Hood's response to be 'one of the best contemporary appraisals of Clare's work as a whole' ${ }^{10}$ The only substantial study of Edwin Paxton Hood is an article by Brian Maidment who focuses on the rhetorical and polemical strategies of his genre-busting 'exemplary' biographies. ${ }^{11}$ Other than these two instances, recent scholarship has overlooked Hood, even though he was committed to Clare as part of his general cause across twenty years of his prolific writing life, some of it while Clare was still alive. As with Frederick Williams above, Hood is among many instances of writers giving the lie to the still prevalent idea that Clare was 'forgotten' in the middle to late nineteenth century.

Hood's The Literature of Labour provides the first major critical essay on Clare which is not hampered by a patronising set of class-based excuses and pity for Clare's impecunious lot. In so doing, it effectively clears the ground for all confident Clare criticism to come. Though it does romanticise the poet's peculiar sensitivities and physical frailty, Hood's critique lacks the prevalent anxiety over Clare's status we can readily track through nineteenth- and twentieth-century 
critics. With all the didactic, polemical assertiveness of a committed liberal working against the conventional Victorian equation of economic power with moral worth, Hood claims that 'we may call Clare the Wordsworth of Labour', and is detailed, and convincing, as to why. Introducing Clare's 'Sighing for Retirement' and the talismanic lines in question, Hood writes:

The following lines are very touching, when it is remembered that they are the pensive utterance of a soul ill at ease from the very frailty of the tabernacle in which it is confined -a house too fragile for the strong spirit within it - the cause at once of every poet's madness. His organic sensibility, his nervous nature responding to every varying tone and intimation, and his strong soul desiring to overleap the material pales and boundaries, and live entirely in the land, visiting it in his poetic dreamings... ${ }^{12}$

The expression of Hood's upon which I wish to focus, is 'desiring to overleap the material pales and boundaries and live entirely in the land'. Pales could simply refer to wooden stakes or poles used as part of a fence - or indeed fences in their entirety; Hood could also mean plots, territories, marked out by boundaries; or, more abstractly, pale could signify a 'realm or sphere of activity, influence, knowledge, etc.; a domain, a field' (all OED). Clare's poetic leap for Hood is into a process of desiring, a process of boundary-breaking, an ongoing project of desire to 'live ... in the land' (emphasis added), to go beyond demarcated territories, to break with accustomed situation in order to write - we could borrow from Deleuze and Guattari and say that Hood sees deterritorialisation in writing, or rather finding, poetry. He is not on the land, or with the land, or a few miles above it: but in it. Hood sees Clare as the mole, rather than the eagle-surrounded by earth, encapsulated by fields. For Hood, as for Ashbery, Clare poeticises a 'desiring' to close the gap between himself and the land: in other words, as a poet he works against the physical, conceptual and subjective separation of himself from the natural world, against the normative separation of his subject position from nature as object.

Clare's might have been an impossible dream, but I would maintain that 'in' is the direction in which his most significant work and commentary points: in is set against both anthropocentrism, and the outward exhalations of Romantic egotism (as I have contended elsewhere ${ }^{13}$ ). The two lines work against the accustomed practices and purposeful poise of the conventions of poetic composition, of deliberative, egotistical poetic agency. Before offering my own reading of the lines, I should suggest why subjectivity is so important a concept to ecocriticism.

\section{Green Writing, Green Reading}

In Ecology Without Nature, Timothy Morton pushes against dead-end traits of didactic ecocriticism, especially the positivism governing the local and the natural in ecocritical thought, which is keen to see the consumerist human subject abhorred, and the objectification of nature brought into question..$^{14}$ Morton analyses the categories and assumptions upon which ecocritical thinking founds itself-defining an alternate set of co-ordinating tools and critical concepts such as ambience, ecorhapsody, ecomimesis and the beautiful soul, on his way to a configuration he calls 'dark ecology' - a form of deep ecological criticism which is aware of, and formulated by, the paradoxes which always problematise a critical position concerned with the relationships between man and environment, culture and nature. Morton is polemical when he probes the problems, paradoxes and downright disabling impossibilities of 'closing 
the gap' between the human subject and natural object:

Nature writing always tries to be 'immediate' - to do without the processes of language and the artful construction of illusions. It wants to maintain the impression of directness. But this can only be a supreme illusion, ironically, in a world in which one can find a Coke can in Antarctica. The immediacy that nature writing values is itself as reified as a Coke can.

Nature writing partly militates against ecology rather than for it. By setting up nature as an object 'over there' - a pristine wilderness beyond all trace of human contact-it re-establishes the very separation it seeks to abolish. We could address this problem by considering the role of subjectivity in nature writing. What kinds of subject position does nature writing evoke? Instead of looking at the trees, look at the person who looks at the trees. ${ }^{15}$

What Morton attempts to do to ecocritical thought is momentous: he suggests that, rather than focusing its efforts on denying the validity of anthropocentrism, ecocriticism should train its analysis upon the situated human subject who constructs the world and 'nature' ideologically. Logically enough, Morton follows up this non-violent 'call to arms' for us to be critically aware of the traps of 'ecomimesis', not with a reading of an eco-poem by Clare (such as 'The Badger', 'Lament of Swordy Well' or 'The Fallen Elm'), but with the doleful 'I Am'. For me, this poem is the ultimate statement of the troubled self; the end-stop of the arc of the Romantic subject, finally old, bitter and crassly misogynist, yet unsure of itself, and wishing to dissolve all responsibility of selfhood in and among the enveloping green grass of death. For Morton, however, the poem 'defeats trite ecological sentimentality' and confirms happily that 'at the limits of subjectivity, we find closeness to the earth' ${ }^{16}$ This irresolvable and acute awareness of the problematic 'nature of nature', when conceived of by a destabilising Romantic subjectivity, informs my own reading of the two lines from 'Sighing for Retirement'. I think the lines can serve as a pithy, symptomatic example in the understanding of Clare's green subjectivity, which in turn could inform the manners and methodologies by which his texts might be re-presented in the future.

For Clare in the two talismanic lines of 'Sighing for Retirement', text is the issue of something prior: poetry exists somewhere and sometime before text. Text is remnant, partial record, echo and trace. The field of this experience of discovery renders the writing subject of little or no significance. The writer becomes scribe, passive conduit, lightning conductor for something so powerful it courses through him to the page, with a sweeping dismissal of the writer's input. This is not just a model of organic authorship - it is also a model of the natural world - which communicates blankly - and communicates before man wanders accidentally upon the offerings of its meaning system - and continues to express long after man has quit the scene. In this model, it is man, rather than nature, who is vacancy, who is blank amanuensis. Shelley's 'human mind's imaginings' which seem to offer the only expression of, and meaning for, the void of nature's 'vacancy', are of no consequence here; actually Clare's lines invert Shelley's troubled interrogative which ends, and effectively re-opens, 'Mont Blanc' ${ }^{17}$ Clare's God-fearing poet lies prostrate at the temple of a nature which cares not a jot for him - and the poet loves it - the poet lives off the discovery and his passivity in the reception of it. Crucially, impossibly, perhaps foolishly, Clare's model claims to close the subject / object gap by denying subjectivity and agency to what we should no longer call the writing subject, and by providing communicative, artistic purpose, 
to a living entity, object no more. The poet is little more than a delivery boy of exchange in fields of meaning, and is part of a project which he claims (and Ashbery believes) is beyond his understanding. The poet denies much active function to himself, but this is not necessarily evidence of social humility or self-effacing modesty. There is a long tradition behind Clare's faux-naïve self-presentation of course: he places himself squarely in the earliest 'troubadour' line as creative finder and discoverer, rather than the poesis model of creative maker, Romantic originator, or Coleridgean fountain. ${ }^{18}$

Clare, as nature's delivery boy and troubadour, bidden by God, turns up the location of the strands of text which need picking up, copying down and re-delivering: any social 'humbleness' Felstiner reads, actually masks the implication that this poet is ethically superior to the aesthete, to the plotter, the schemer, the botaniser, the scholar or the documentor. As Morton says, more generally, '[e]comimesis works very hard at immersing the subject in the object, only to sit back and contemplate its handiwork', ${ }^{19}$ and that is partly what Clare is attempting here. Yet he contemplates not just his handiwork, but also the ways in which his 'taste and love' see things 'common eyes' ignore. This poem is one of a number of instances where Clare claims to be part of an élite who see and understand in ways and modes the common order cannot manage (this self-important snobbery in Clare is rarely acknowledged, but has been recently analysed by Adam White ${ }^{20}$ ).

Clare conceals his knowledge of his routes of access to this super-sensory situation, because he has become her, if we can allow nature as woman for the purposes of this analysis. ' $\mathrm{It}^{\prime}$ does not fully signify what Clare is conceiving here, whereas to address nature with the pronoun 'her' is to empower 'her' with a subject position of her own (though one admittedly of a man's making). Closing the distance between man and nature has meant the poet is not only implicit in the natural world, but also suggests a rare achievement: the distinctions between man and nature, between nature and culture, have dissolved. The poet has abrogated these manmade categories. He is the natural world: he is becoming nature-and embodying nature, as she disembodies him through textual exchange. Effectively he undermines the necessity of an ontological category called 'nature'. The poet is entwined so much with nature that he cannot distinguish his own subject position from hers - nor does he want to. The field of meaning of his own experience segues into her physical fields - at the very least, such unification is clearly implicated. Thought and ground, text and texture, are in a process of becoming one. In this poem, nature does not give him a voice: she instructs. Clare cleanses the problems, the compromises, the iterations, alterations and altercations of socialised authorship here too-erasing as he does so the significance of the 'critic's pen'. It is important to note that, in this poem, Clare does not compensate for his disdain of literary sociability by putting his poet in a familial structure of relation with the natural world. She is not a cosy retreat, and not Mother Nature, but Lover Nature. The power of the mother is denied; the anthropomorphisation of the natural field is disavowed; the imposing hierarchies of relation with editor, with audience, with other poets, with critics, are erased. The poet is nature, so is beyond criticism. But logically and mutually, nature has wiped out the role of the poet too. He is re-inscribed as fields of semiotic multiplicity; on acres of passive, flat, as-yet-unwritten paper. The poetry itself is not inspired, it is perspired. In this model, the poetic text becomes the emanation of a bodily congregation, of an assemblage, to use Deleuze and Guattari's terminology. The poet's disembodiment, his unimportance, his eradication, is proof of the power of green fecundity. This is poet as the 
Christ: the conduit, the purposeful, polemical, lonely self-sacrificer, embodying another ontological field. The instability of this position resolves itself conventionally, safely, though - as with 'I Am' - not entirely convincingly, in a closing recourse to God.

In 'Sighing for Retirement', poetry is not the sublime expansion of the ego, but the orgasm of its death, of its annihilation at the moment it renders itself into the levelling body of nature, at the moment it becomes a text, marking its own passivity and diminution in submission to a non-human other, Lover Nature. Actually the poet does not 'listen' conventionally to nature; she does not communicate with him either (the third line reads 'Nature's voice is never loud' after all). But loving, listening and communicating require dialectic distance to be defined between the existence of interlocutors, between bodies gazing, hearing, sniffing or entwining. In this model, such distance is closed: writing subject becomes natural object, and so there is no body. Subjectivity is thought and materiality; materiality unproblematically produces text; subjectivity is also becoming the state and status of the object. The object is trace, is textuality; subject / object positions, individuality and locality - all are absorbed as delimiting categories of separation and position into a limitless and multiplying unification of intersubstantiating process - an ongoing, de-centred activation, prospecting beyond subject / object dualism.

If this reading of 'Sighing for Retirement' is characteristic of Clare's radical take on the relationship between his poetic art and the natural world, we might consider what implications such a conceptualisation could have for textual criticism. In the context of Clare studies, it might seem antithetical to introduce here a strand of thought which suggests that ecological thinking should not be static or rooted to one place or locality. In The Three Ecologies, originally published in 1989, Felix Guattari writes, provocatively:
Environmental ecology, as it exists today, has barely begun to prefigure the generalized ecology that I advocate here, the aim of which will be to radically decentre social struggles and ways of coming to one's own psyche. Current ecological movements certainly have merit, but in truth I think that the overall ecosophical question is too important to be left to some of its usual archaizers and folklorists (...) Ecology must stop being associated with the image of a small nature-loving minority or with qualified specialists. Ecology in my sense questions the whole of subjectivity and capitalistic power formations, whose sweeping progress cannot be guaranteed to continue as it has for the past decade. ${ }^{21}$

As well as being expansive beyond the oikos, the home, and the local, ecological thinking has to admit that 'nature' is mind-made, that the 'environment's' troubled ground is human subjectivity - as Timothy Morton similarly contends:

We are treading a path between saying that something called nature exists, and saying that nothing exists at all. We are not claiming that some entity lies between these views. We are dealing with the raw materials of ideology, the stuff that generates seductive images of 'nature'. That is why it is important to go as 'far in' to the notion of nature in ecomimesis as possible. ${ }^{22}$

This essay will extend Guattari's and Morton's parallel varieties of urgency, to argue that ecological literary criticism needs to interrogate the construction of the raw materials of its work: needs to turn from its construction of nature, to the making of text. 
From the Closed Gap to the Green Text

Michael P. Branch rightly maintains that 'scholars of environmental literature have been slow to recognize the need for and importance of textual editing ${ }^{\prime 23}$ The object of his argument is to stimulate ecocritics to make accessible the forgotten texts of 'nature writing'. No ecocritic has as yet taken the next logical step to explore the potential for ecological theory to inform an editorial methodology which might support the creation of 'green' text. In a discussion of genetic criticism, Louis Hay points out that 'editing has always embodied the main ideological and cultural concerns of its day' ${ }^{24}$ Because the context of editing Clare has always been determinedly political and ideological, as I have suggested elsewhere, ${ }^{25}$ and because it has been such fiercely contested ground in the recent past, ${ }^{26} \mathrm{I}$ think it would be healthiest and methodologically most sound, to be explicit about the political colours and agendas of future editorial projects. What follows is an admittedly idealistic consideration of what might be possible in the future of editing and presenting Clare's texts.

The 'language-war' model of textual presentation of Clare results from demonstrably oppositional politics which inform either camp of editorial methodologies, and has rendered the presentation of texts monologically for the most part: in summary, this has seen the dominant 'primitivist' mode of transcription take a politicised stance against 'polishing' editorial interventionism. The primary, foundational editorial choice over whether to leave texts ' $\mathrm{raw}^{\prime}$ ' or to ' $\mathrm{cook}^{\prime}$ them, informs all subsequent editorial choices. ${ }^{27}$ In contrast, an editorial methodology which is green in its political foundation will necessarily promote inclusive interconnectedness between and among manuscript and editorial variants, as a salve to the exclusive nature of Clare editing across the last fifty or so years. Where ecological theory tries to remove man from the top of an assumed hierarchy and to level and merge his subject position with the network of other parts of the natural world, so we might use a de-centred and levelling hypertextual frame for the presentation of Clare's texts: here an editor would become a facilitator for user-interactivity rather than a prescriptive determiner of the sort of text a reader will encounter. This editorial model would deploy an enriching interconnectedness, a branching 'rhizome' (to use Deleuze and Guattari's concept of interrelation) of relation between which is evocative of how mutual interdependence is a dominant motif for understanding (and for idealising) human relations with nature. A green editorial presentation would maintain the provisional nature of textual experience, would defer any 'final' decisions about what sort of text or texts should be central, to the user.

Such an editing project would maintain and foreground the provisional nature of text, and so follow Felix Guattari's key assertion in The Three Ecologies that 'eco-logic no longer imposes a "resolution" of opposites' ${ }^{28}$ Stuart Moulthrop has demonstrated the potential of understanding hypertextual networks as rhizomes $^{29}$ and, more broadly, hypertextual theory has repeatedly concerned itself with the decentred, multivocal and provisional possibilities of internet textuality - deftly summarised by George P. Landow ${ }^{30}$ - yet no work has been carried out on the ways in which ecological theory might forge a methodological and ethical bridge between the limitations of print-based media and new electronic textual technologies.

Thorough work has been carried out, however, on the benefits of 'genetic' hypertetxtual editing, which frames textuality and textual provenance in much the same way as I am suggesting 'green' editing could do. In the long quotation that follows, Daniel Ferrer 
summarises the potential advantages of hypertextual genetic editing:

The traditional model of apparatus, presenting one text with a plurality of variants, is totally inadequate to the task: it involves a linearization of something that is not linear; it introduces an artificial hierarchy between elements that are only retrospectively hierarchized; and it causes not only a loss of the energy that nobody who enters into contact with drafts can ignore, but also a sheer loss of information.

Genetic work clearly requires facsimiles of the documents, but it is not enough to deliver to the reader a bundle of rough material. It is often necessary to provide a transcription, and in some cases, alternative transcriptions, since any transcription is an interpretation. But the inclusion of transcriptions in the sequence of facsimiles only makes more difficult the insoluble problem of ordering the documents. Genetic files are multidimensional objects, and linear representations, such as books can offer, are necessarily mutilating. There is always a multiplicity of possible genetic orders, and each of them tells a different story. The mere juxtaposition of the manuscripts introduces, under the guise of total neutrality, an unacknowledged bias. The only way of bypassing this sly form of control is to provide a multiplicity of solutions.

Undoubtedly, hypertextual presentation gives the best chance to do justice to the diversity of the material and the multiplicity of the relationships. It offers an unlimited number of paths through the documents; it allows instant juxtaposition of facsimiles, transcriptions, and commentaries (which can be as long as necessary, in various depths of accessibility, so as not to stifle the manuscripts themselves); and it welcomes dialogic readings, with unlimited possibilities of reordering, additions of new documents, and changes of readings (which are inevitable for most complex manuscripts). ${ }^{31}$

Ferrer is idealistic, provocative and liberating. $\mathrm{He}$ is also censorious. He rails against the 'sly form of control' of many editing projects, but at one point he claims genetic editing has a bedrock of 'common sense'. He then asserts that the genetic editor's resistance to 'absolute editorial decisions' does not emerge 'out of poststructural theoretical prejudice, but as the result of our daily experience with writers' manuscripts' ${ }^{32}$ He resists and rejects theory, claiming for his own editorial ideals the firm, empirical ground of hard-won experience at the manuscript coalface. Unlike Louis Hay, Ferrer does not allow for any ideological basis for the claimed superiority of the genetic critical approach: 'common sense', he implies, is its raison d'être and is justification enough.

Nevertheless, Ferrer's discussion of the de-stabilising multiplicity of the genetic text, the provisional nature of textual source and of deferred decisions over editing, are editorially liberating. From here, I would like to extend Hay's ideological understanding of editorial methodologies to questions of subjectivity. If Jonathan Maskit is right to claim that '[q]uestions about subjectivity often either are absent from environmental philosophy or tend to offer an account of some "natural" form of subjectivity that is somehow being violated $\ldots{ }^{133}$ a parallel absence of discussions of subjectivity in editorial projects is even more acute. I would like to suggest that the political positioning inherent in the production of any edition, determines individual subjectivity as maintaining a sort of 'consciousness' of the textual life of the edition. We might say that any edition - in having standards, coherent practices that inform the decisions constructing the transcription and rendition of the manuscript holograph (should there be one) into typewritten text - therefore attempts to dress itself as a coherent mechanism for the 
safe, linear delivery of a set of writings. Even in ostensibly all-inclusive variorum editions, the methods construct a certain version of the writer, of a period, of a genre, and so on -in other words an individualised, fixed position: a rationalised, codified, and standardised sense, made out of the chaos of archives and manuscripts - but made despite that chaos, not because of it. Genetic editing prefers the term 'avant-texte' to 'variant', ${ }^{34}$ because the latter determines, naturalises and finalises the choice made over what the central text is to be: all other texts are variations from this mainstay, which will become the 'copy text'. For practical considerations in book printing - but for ideological reasons too - the journey to the choice over copy text often remains latent. In genetic criticism, it is permanently deferred.

The courage of an editor faced with mountainous brambles of manuscripts, is that of a lion tamer, wrestling and conducting wildness into submission, and coaxing disarray into order. Therefore a 'standard' scholarly edition has a univocal intentionality and a particularising version of the author's subjectivity latent in the 'genetic code', if you will, of the editing methodology. I would argue that this has been the case in the editing of Clare. It might be that the presentation of texts can be no other way, and there is not necessarily anything wrong with this: an edition will always enhance access to something, and in so doing must channel, guide and make clear, centred and coherent what is otherwise messy and dispersed. But what could also be the case is that the construction of a coherent textual subjectivity through the deliberate - if not always explicit-machinations of an editorial methodology, represses exactly the sort of multiplying variety and manuscript faithfulness to which a variant edition is designed to adhere. Such an edition might reify a certain version of the author's intentionality, might codify and authorise something which is more to do with the considered subject position of the editor, than the original author who is, after all, nowhere, other than in text. Texts reproduced under the aegis of such a book project, therefore become mutually confirming, in the construction of an overarching singular authorial subjectivity. We edit, therefore Clare is. The destabilising contradictions, vacillations, paradoxes, fluidities, declarations and immolations of a varied textual life, are whittled away in the construction of an edition which seeks uniformity and consistency for its singular subject-even where it commits to include notations of all textual variants. In an edition like the Clarendon Oxford Clare, there is a crucial temporal disjunction between the time-span of the poet's writing life which produced the work diachronically, and the presentationally and editorially synchronous delivery of all poems according to a set method which shapes all texts included. The following quotation from the Oxford Clare editors' introduction, is illustrative of the problems arising from their determination to present Clare according to a set methodology:

As Clare matured and became more confident he tended to reduce punctuation to a minimum both in prose and verse. In some of his early poems, in the versions submitted to Drury, however, he fell into the opposite extreme, probably in response to suggestions coming from several quarters that he ought to be more 'correct'. When he did this the punctuation became so excessive that it seriously interfered with the reader's enjoyment of the poetry. We have therefore removed the punctuation when it was clearly wrong but have provided the evidence of exactly what we have done. ${ }^{35}$

The early Clare does not match an ideal version of a later-and by implication, better-Clare, so the editors are compelled to intervene by the force of logic of their own method. Across all 
nine volumes, the fifty years or so of Clare's varied writing life are channelled through a homogenising editorial process which will try to produce poetry 'in the raw', sometimes despite the original source material. In seeking to deliver an overall similitude across texts produced by the wide varieties of Clare's language strategies, this edition tries to resolve problems which I contend are irresolvable and ongoing. They are problems of expression, orthography and presentation that Clare, like many other writers, raises and then writes through, but never finally answers, because such problems remain unanswerable, and the creative responses varied and inconsistent.

A green hypertextual edition of Clare would not have to try and resolve any of the problems sketched here, and would not try to clamp down or delineate a pre-determined version of Clare's subjectivity (through a static overarching version of his position on the politics of linguistic standardisation, for example): it would maintain instead his peculiar problems, enjoy them, and project the chaos. It could present the manuscript versions (in facsimile and a variety of transcription styles) and the lifetime-published texts. It would deliver variously, and provisionally, defer and project possible closing judgements but never reach or isolate them. It would enable a reader (can we bibliophiles ever be happy with 'user'?) to determine the sort of textual experience desired. Its purpose would be to promote the excitement and trouble produced by clashes, by the instabilities of the 'avant-texte', by contradictions of editorial transcription choices, by inconsistencies of representation, by multi-vocalities, by pluralities - those both at manuscript source, and at the editorial 'end' of transcription style. It would see a singular authorial subject turned into a de-centred textual rhizome of networks and nodes. This green editorial methodology would question the reification of a particular editorial subjectivity and would instead deliver something which is unmanaged, untrammelled, uncompromised, wild, and rough and smooth, spikey and unsettling. The user would read in spaces of interlocking planes of textual fields, open and green for the discovery and manipulation of poems presented in order that they could be ceaselessly, freely re-made according to whatever sort of textual experiences the user wishes to pursue. Unlike Clare's poet of discovering texts in the fields, the reader would be made fully aware of the agency necessary to reading, and of the choices available which become a foundational part of the process of engagement with overtly greened hypertexts.

\section{Oxford Brookes University}

Notes

1. Frederick S. Williams, The Midland Railway: its Rise and Progress. A Narrative of Modern Enterprise (London, 1876), vii and viii. The reference to Clare is on 597.

2. C. Day Lewis, The Lyric Impulse (London, 1965), 111.

3. Harold Bloom, The Visionary Company: A Reading of English Romantic Poetry, rev edn (New York, 1971), 448.

4. Paul Chirico, John Clare and the Imagination of the Reader (Basingstoke, 2007), 138-9.

5. John Felstiner, Can Poetry Save the Earth? A Field Guide to Nature Poems (New Haven, 2009), 58.

6. John Ashbery, 'John Clare: "Grey Openings Where the Light Looks Through"', in Other Traditions (Cambridge, MA, 2000), 1-22, 16-17. For an extended account of Clare's significance to both Ashbery, and to the future of American environmental poetry, see Angus Fletcher, A New Theory for American Poetry: Democracy, the Environment and the Future of the Imagination (Cambridge, MA, 2004).

7. Cyrus Redding, 'Clare, the Poet', The English Journal, 20 (15 May 1841), 305-9. The essay continues in the same publication, 22 (29 May 1841), 340-3. For an extracted text, see Mark Storey, Clare: The Critical Heritage (London, 1973), 247-56.

8. Cyrus Redding, Past Celebrities Whom I Have Known (London, 1866), 135. 
9. Brian Maidment, 'Popular Exemplary Biography in the Nineteenth Century: Edwin Paxton Hood and His Books', Prose Studies, 7. 2 (September 1984), 148-67.

10. Mark Storey, 'Edwin Paxton Hood (Not the Reverend Romeo Elton) and John Clare', Notes and Queries, 18.10 (October 1971), 386-7, 386.

11. Maidment, 148-67.

12. Edwin Paxton Hood, The Literature of Labour, 2nd edn (London, 1852), 123.

13. Simon Kövesi, 'John Clare's "I" and "eye": Egotism and Ecologism', in Green and Pleasant Land: English Culture and the Romantic Countryside, ed. Amanda Gilroy (Leuven and Paris, 2004), 73-88.

14. For a brief summary of these issues, see Karla Ambruster, 'Speaking for Nature', in Literature of Nature: An International Sourcebook, ed. Patrick D. Murphy (Chicago, 1998), 429-33.

15. Timothy Morton, Ecology Without Nature: Rethinking Environmental Aesthetics (Cambridge, MA, 2007), 125.

16. Morton, 200. The reading of 'I Am' also appears in Timothy Morton, 'John Clare's Dark Ecology', Studies in Romanticism, 47 (Summer 2009), 179-93.

17. Percy Bysshe Shelley, 'Mont Blanc', The Complete Poetical Works of Percy Bysshe Shelley, ed. Neville Rogers (2 vols, Oxford, 1975), ii. 75-80, 80.

18. Samuel Taylor Coleridge defensively maintains himself as an originating 'fountain' in the prose preface to Christabel, in anticipation of criticisms that it had derived from celebrated poems upon which it had wielded some influence, through pre-publication readings and circulation. Samuel Taylor Coleridge, Poetical Works, ed. J. C. C. Mays, The Collected Works of Samuel Taylor Coleridge, Bollingen Series 75, 16 (6 vols, Princeton N. J., 2001), vi. 482.

19. Morton, 135.

20. Adam White, 'John Clare: "The Man of Taste", John Clare Society Journal, 28 (2009), 38-54.

21. Felix Guattari, The Three Ecologies, trans. Ian Pindar and Paul Sutton (London, 2000), 52.

22. Morton, 68.

23. Michael P. Branch, 'Saving All the Pieces: the Place of Textual Editing in Ecocriticism', in The Greening of Literary Scholarship: Literature, Theory, and the Environment, ed. Steven Rossendale (Iowa City, 2002), 3-25, 5.
24. Louis Hay, 'Genetic Editing, Past and Future: a Few Reflections by a User', trans. J. M. Luccioni and Hans Walter Gabler, Text: Transactions of the Society for Textual Scholarship, 3 (1987), 117-33, 117.

25. Simon Kövesi, 'Beyond the Language Wars: Towards a Green Edition of John Clare', John Clare Society Journal, 26 (2007), 61-75 and 'The John Clare Copyright: 1820-2000', Wordsworth Circle, 31 (Summer 2000), 112-9. For alternative accounts of the editing and copyright debate, see Jennifer Wallace, 'Dead Poet's Propriety', Times Higher Education Supplement (13 August 1999), 15 and Eric H. Robinson, 'John Clare Scholarship and Copyright' [letter], Times Literary Supplement (1 September 2000), 17. Also see the editorial introductions to The Later Poems of John Clare, 1837-1864, ed. Eric Robinson and David Powell (2 vols, Oxford, 1984), The Early Poems of John Clare, 1804-1822, ed. Eric Robinson and David Powell (2 vols, Oxford, 1989) and John Clare: Poems of the Middle Period, 1822-1837, ed. Eric Robinson, David Powell and P.M.S. Dawson (5 vols, Oxford, 1996-2003). For a counter argument, complicating and defending 'polished' texts, see Jonathan Bate, 'Note on This Selection' in 'I Am': The Selected Poetry of John Clare (New York, 2003), xv-xxiii, and his John Clare: A Biography (London, 2003), 563-75.

26. For a bibliography of responses to the editorial controversies centring on Clare, see the 'Copyright' section of The John Clare Page, ed. Simon Kövesi, http://www.johnclare.info

27. Clear summaries of these issues in relation to editing Clare are provided by R. K. R. Thornton in 'What John Clare Do We Read?', PN Review, 31. 4 (March-April 2005), 54-56, and 'The Raw and the Cooked', John Clare Society Journal, 24 (2005), 78-86.

28. Felix Guattari, The Three Ecologies, trans. Ian Pindar and Paul Sutton (London, 2000), 52.

29. Stuart Moulthrop, 'Rhizome and Resistance: Hypertext and the Dreams of a New Culture', Hyper / Text / Theory, ed. George P. Landow (Baltimore, 1994), 299-319.

30. George P. Landow, Hypertext 3.0 (Baltimore, 2006), 56-65.

31. Daniel Ferrer, 'Production, Invention, and Reproduction: Genetic vs. Textual Criticism', 
Reimagining Textuality: Textual Studies in the Late Age of Print, ed. Elizabeth Bergmann Loizeaux and Neil Fraistat (Madison, 2002), 48-59, 55-56.

32. Ferrer, 56-7.

33. Jonathan Maskit, 'Subjectivity, Desire, and the Problem of Consumption', Deleuze | Guattari \& Ecology, ed. Bernd Herzogenrath (Basingstoke, 2009), 129-44, 130.
34. For a full account, see Daniel Ferrer and Michael Groden, 'Introduction: A Genesis of French Genetic Criticism', Genetic Criticism: Texts and Avant-textes, ed. and trans. Jed Deppman, Daniel Ferrer and Michael Groden (Philadelphia, 2004), $1-16$.

35. The Early Poems of John Clare, 1804-1822, ed. Eric Robinson and David Powell (2 vols, Oxford, 1989), i. xxiii. 